\title{
Developments in Bioremediation of Soils and Sediments Polluted with Metals and Radionuclides \\ 2. Field Research on Bioremediation of Metals and Radionuclides
}

Terry C. Hazen ${ }^{1}$ and Henry H. Tabak ${ }^{2}$

${ }^{1}$ Lawrence Berkeley National Laboratory, Virtual Institute for Microbial Stress and

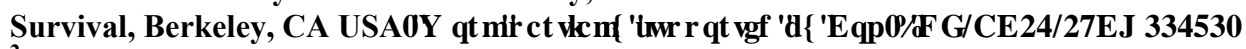

${ }^{2}$ US EPA, ORD, National Risk Management Research Laboratory, Cincinnati, OH USA 


\section{INTRODUCTION}

Bioremediation technology uses microorganisms to reduce, eliminate, contain, or transform to benign products contaminants present in soils, sediments, water, or air. Bioremediation is not a new technology. Both composting of agricultural material and sewage treatment of household waste are based on the use of microorganisms to catalyze chemical transformation. Such environmental technologies have been practiced by humankind since the beginning of recorded history. Evidence of kitchen middens and compost piles dates back to 6000 B.C, and the more "modern" use of bioremediation began over 100 years ago with the opening of the first biological sewage treatment plant in Sussex, UK, in 1891. However, the word "bioremediation" is fairly new. Its first appearance in peer-reviewed scientific literature was in 1987 (HAZEN 1997).

The last 15 years have seen an increase in the types of contaminants to which bioremediation is being applied, including solvents, explosives, polycyclic aromatic hydrocarbons (PAHs), and polychlorinated biphenyls (PCBs) (MCCULLOUGH et al. 1999; NABIR 2004). Now, microbial processes are beginning to be used in the cleanup of radioactive and metallic contaminants, though these contaminants present special problems since they cannot be destroyed, only transformed or contained.

There are a number of ex situ and in situ bioremediation methods currently available (Figure 1). Ex situ methods have been around longer and are better understood, and they are easier to contain, monitor, and control. However, in situ bioremediation has several advantages over ex situ techniques. In situ treatment is useful for contaminants that are widely dispersed in the environment, present in dilute concentrations, or otherwise inaccessible (e.g., due to the presence of buildings or structures). This approach can be less costly and less disruptive than ex situ treatments because no pumping or excavation is required. Moreover, exposure of site workers to hazardous contaminants during in situ treatment is minimal. Broadly, bioremediation strategies can be further divided into natural attenuation, biostimulation, and bioaugmentation strategies. Bioaugmentation being the most aggressive, since organisms are added to the contaminated environment. Biostimulation can be aggressive or passive, in that electron donors, electron acceptors, and trace nutrients can be injected into the environment to stimulate indigenous 
organisms to increase biomass or activity to affect the contaminant. Passive biostimulation techniques include simple infiltration galleries or simply spreading fertilizer on surface without any pumping or mixing. Natural attenuation relies on the intrinsic bioremediation capabilities of that environment. Environments high in organic carbon and energy sources, low contaminant concentrations, and without significant nutrient deficiencies may be able to degrade or transform the contaminants of concern without any intervention. Ideally, the most cost effective and efficient approach to treat most large contaminant plumes is to use more aggressive approaches, e.g. bioaugmentation or even excavation and removal, at the source, grading into natural attenuation at the leading edge, or over time as the contaminant concentration declines. There are no bioaugmentation candidates yet for metals and radionuclides that we are aware of. Rarely is a single remediation approach completely effective or cost efficient. Indeed, combining aggressive physical and chemical treatment techniques like chemical oxidation/reduction, thermal desorption with bioremediation can provide advantages to some types of contaminants and allows bioremediation to be an effective polishing or sentinel strategy for the cleanup.

\subsection{BIOREMEDIATION STRATEGIES FOR METALS AND RADIONUCLIDES}

Over the past few years, interest in bioremediation has increased. It has become clear that many organic contaminants such as hydrocarbon fuels can be degraded to relatively harmless products like $\mathrm{CO}_{2}$ (the end result of the degradation process). Wastewater managers and scientists have also found that microorganisms can interact with metals and convert them from one chemical form to another. Laboratory tests and ex situ bioremediation applications have shown that microorganisms can change the valence, or oxidation state, of some heavy metals (e.g., chromium and mercury) and radionuclides (e.g., uranium) by using them as electron acceptors. In some cases, the solubility of the altered species decreases and the contaminant is immobilized in situ, e.g., precipitated into an insoluble salt in the sediment. In other cases, the opposite occurs - the solubility of the altered species increases, increasing the mobility of the contaminant and allowing it to more easily be flushed from the environment. Both of these kinds of transformations present opportunities for bioremediation of metals and radionuclides - either to lock them in place, or to accelerate their removal. Microorganisms can do much more than biotransform contaminants. They can also influence contaminant behavior by changing the acidity of the system in the immediate vicinity of the contaminant, or by altering the form of 
organic compounds that influence radionuclide and metal mobility (Figure $2 \& 3$ ). A significant number of field studies and successful deployments using bioremediation strategies for metals and radionuclides have occurred recently. Under the general categories of biotransformation, bioaccumulation/biosorption, biodegradation of chelators, volatilization, treatment trains \& natural attenuation we will provide some example case studies for a variety of metals and radionuclides. Detailed examples of laboratory studies and fundamental research on the nature of bioremediation of metals and radionuclides can be found in the companion chapter in this book (Tabak et al., chapter 29)

\subsection{CRITICAL BIOGEOCHEMISTRY}

The state and fate of metals in all environments is highly dependent on the redox or valence state of the metal. The redox potential of the environment will control the direction of chemical equilibria and whether the metal is reduced or oxidized. This in turn controls the possible compounds that the metal can form and the relative solubility of these metals in the environment. To stimulate microbes to produce conditions that are appropriate for remediation of specific contaminants requires a through knowledge of the geochemistry of that environment. Since electron acceptors vary greatly as to the energy that can be derived from their use in respiration, the most common terminal electron acceptors (TEA) will be utilized in a set order, according to the energy that can be derived (Figure 4). Thus, oxygen is the preferred TEA and first TEA to be utilized, followed by nitrate, iron (III), sulfate, and carbon dioxide. Since reduction of $\mathrm{Cr}$ and $\mathrm{U}$ is not favored until the redox potential is in iron reducing conditions, these two TEAs would have to be depleted first. Indeed, for sites that also have PCE/TCE the iron (III) and the sulfate would have to be depleted before sustained methanogenesis and subsequently halorespiration can occur. For field applications, this means that enough electron donor would have to be added to deplete all the oxygen and nitrate present, at a minimum. By monitoring the TEA and their daughter products, it provides an excellent measure of the redox conditions at the site and the potential for degradation of the contaminants of concern.

As an example of the importance of $\mathrm{pH}$ and Eh, Uranium forms a number of different compounds in the environment with U(VI) being generally more soluble and thus mobile then $\mathrm{U}(\mathrm{IV})$. As seen in Figure 5 the U(IV) stability region extends to higher Eh as $\mathrm{pH}$ decreases. 
Thus $\mathrm{U}$ bioreduction for immobilization of U(IV) is expected to be more sustainable under slightly acidic conditions. The trade off is that the U(VI) sorption is weaker and U(IV) is soluble at $\mathrm{pH}<4$.

\subsection{CHARACTERIZATION AND MONITORING CONSIDERATIONS}

The success of any bioremediation application will be highly dependent on the characterization and monitoring that is done before and during the field deployment. For any field remediation, the first step is to form a conceptual model of the contaminant plume in the environment and how that environment effects that plume. The uncertainties in this conceptual model provide the drivers for the characterization and monitoring needs. For example, characteristics of the aquifer will have a profound impact on the remediation strategy (Table 1). The largest part of the expense of any remediation project is the characterization and monitoring. Hydraulic conductivities can have a severe effect on your ability to deliver nutrients to the subsurface (Table 2) and can be the most limiting part of the environment. However, as discussed above if bioreduction was the strategy for a metal contaminated site and the site had a hydraulic conductivity of only $10^{-8} \mathrm{~cm} / \mathrm{sec}$ with very high nitrate and sulfate levels and high $\mathrm{pH}$ it may not be cost effective to use bioreduction at this site. These issues also suggest why bioaugmentation has not lived up to its hope. Though bioaugmentation promises 'designer biodegraders', it has not proven to be better then biostimulation in repeated field trials over the last 2 decades. Indeed, there is only one bacterium that has demonstrated that it can perform better then biostimulation in situ on some occasions, Dehalococcoides ethenogenes for dehalorespiration of chlorinated solvents. At least two products are commercially available and have been widely used in the U.S. that are proprietary strains of this organism (Regenesis and Geosyntec). We suspect the reason that this microbe has been successful is that it is a strict anaerobe, chlorinated solvent dehalorespiration requires established methanogenic redox potentials, and the organism is very small irregular coccus $(0.5 \mu \mathrm{m})$ so it can penetrate the subsurface more easily (LOFFLER et al. 2000). Patchy distributions of this organism in nature are also common, so bioaugmentation may provide a couple of advantages. Fortunately, new advances in geophysics and hydraulic push technology (Geoprobe) has enabled us to characterize sites in a fraction of the time and cost. Once we have established the hydrology and basic geochemistry at the site and used that data to refine our conceptual model, a base line characterization of the 
microbiology is essential to establish that the right microorganisms are present, that they can be stimulated, and that no undesirable reactions with the stimulants or daughter products from the stimulation will occur. This usually requires some treatability and soil compatibility studies and monitoring of microbial community structure and function to establish the base conditions prior to stimulation (PlAZA et al. 2001). For example, some metals like arsenic actually increase solubility under the same redox potentials that precipitate $\mathrm{Cr}$ and $\mathrm{U}$. Table 3 provides an example list of the types of measurements that should be performed from either treatability slurries, soil columns or in situ sampling (HAZEN 1997). This data and the refined conceptual model provide the functional design criteria for the remediation and can be used to develop a numerical model to predict the remediation rates, stability and legacy management needs, e.g. monitoring, especially if the remediation is an immobilization strategy.

\section{BIOTRANSFORMATION (BIOREDUCTION AND BIOOXIDATION)}

Unfortunately, metals and radionuclides cannot be biodegraded. However, microorganisms can interact with these contaminants and transform them from one chemical form to another by changing their oxidation state through the adding of (reduction) or removing of (oxidation) electrons. In some cases, the solubility of the transformed metal or radionuclide increases, thus increasing the mobility of the contaminant and allowing it to more easily be flushed from the environment. In other cases, the opposite will occur, and the transformed metal or radionuclide may precipitate out of solution, leading to immobilization. Both kinds of transformations present opportunities for bioremediation of metal and radionuclides in the environment - either to immobilize them in place or to accelerate their removal. All of the field studies and deployments to date that we could find have used immobilization. Mobilization has been traditionally difficult to justify to regulators and stakeholders at remediation sites because it represents an inherently greater risk if the capture zone does not adequately capture the mobile and usually more toxic contaminant. However, since this strategy removes the contaminant from the environment it is a better long-term strategy especially where episodic changes in the environment due to storm surges, etc. occur. Another critical issue for all biotransformation studies are how stable the transformation is, i.e. does the bioreduced metal reoxidize with exposure to oxygen or changes in $\mathrm{pH}$, this especially critical for Uranium which has a fairly narrow range where it remains insoluble. 


\subsection{CASE 1. AQUIFER CHROMIUM BIOREDUCTION AT HANFORD 100H USING POLYLACTATE BIOSTIMULATION.}

The US Department of Energy produced nuclear materials at the Hanford site for more than 40 years, Chromium was used to prevent corrosion in the cooling towers at the site and as an oxidizer in the nuclear fuel production process. Consequently, the site has a large plume of low concentration $\mathrm{Cr}(\mathrm{VI})$ that is impacting the Columbia River. Previous studies by our group (ToKunaga et al. 2003a; ToKunAga et al. 2001a; ToKunAga et al. 2001b; ToKunaga et al. 2003b) demonstrated that simple organic carbon compounds, like lactate, could stimulate iron reducers in the soil to reduce enough $\mathrm{Fe}(\mathrm{III})$ to $\mathrm{Fe}(\mathrm{II})$ that the $\mathrm{Fe}(\mathrm{II})$ would reduce $\mathrm{Cr}$ (VI) to $\mathrm{Cr}$ (III) and precipitate in the soil. In August 2004, we injected $40 \mathrm{lbs}$ of ${ }^{13} \mathrm{C}$-labeled polylactate into a single well after doing pump tests, tracer tests, treatability studies, and base line geophysics. The complete project design, methods, and results are given at http://esd.lbl.gov/ERT/hanford100h/. Figure 6 shows the Hanford plume and the injection well design and geology.

The polylactate (Hydrogen Release Compound, $\mathrm{HRC}^{\mathrm{tm}}$ ) hydrolyzes to lactate in the aquifer, which is readily utilized by the indigenous bacteria, the rate of hydrolyzation is controlled by the degree of esterization of the polylactate. The HRC was labeled with ${ }^{13} \mathrm{C}$ so we could trace via a stable isotope if the microorganisms that were utilizing the $\mathrm{HRC}$ and to measure rates of daughter product formation. Within 2 weeks, the total density of bacteria had increased more than 2 orders of magnitude from $<10^{5}$ cells $/ \mathrm{ml}$, to more than $10^{7}$ cells $/ \mathrm{ml}$. As expected, the oxygen was depleted first, then the nitrate, and then the Fe(III) with a redox potential of $-130 \mathrm{mv}$ (Figure 7). The sulfate started to go down with production of $\mathrm{H}_{2} \mathrm{~S}$, but was never depleted. Methane was never detected. Within 3-4 weeks of injection, the $\operatorname{Cr}(\mathrm{VI})$ came down in the monitoring wells and stayed well below the levels for drinking water for several months, even after the nitrate and oxygen returned to their original concentrations (Figure 7). Microbial community analyses with $16 \mathrm{~S}$ rDNA microarrays for the entire known ribosome database showed that the diversity increased dramatically. Analysis of the community structure after the injection showed an increase in denitrifiers, followed by increases in iron reducers and sulfate reducers. Even though nitrate was depleted, and iron was reduced, sulfate depletion as a TEA 
was never complete and subsequently methanogens were not observed in any of the samples. After 2 months, the bacteria densities slowly returned to their original densities prior to stimulation with HRC. Drilling and pump tests are being carried out now to determine if the attenuation seen in the geophysical measurements that coincided with the reduction in $\mathrm{Cr}(\mathrm{VI})$ was caused by $\mathrm{Cr}$ (III) precipitates. Long-term studies at this site will be necessary to determine if reducing conditions must be maintained to prevent reoxidation of $\mathrm{Cr}$ (III) to $\mathrm{Cr}$ (VI).

\subsection{CASE STUDY 2: USING MERCURY RESISTANT BACTERIA TO TREAT CHLORALKALI WASTEWATER}

Mercury resistant bacteria have been used recently to detoxify $\mathrm{Hg}$ (II)-contaminated water at lab and pilot scale (Figures 8A and B). Wagner-Dobler and coworkers at the German Research Centre for Biotechnology in Braunschweig captured reduced elemental $\mathrm{Hg}$ in a $20 \mathrm{ml}$ immobilized cell bioreactor, inoculated with a mercury resistant Pseudomonas putida, and subsequently colonized with other mercury resistant strains (WAGNER-DOBLER et al. 2000). A companion study demonstrated successful removal of $\mathrm{Hg}^{2+}$ from chloralkali electrolysis water at laboratory scale (VON CANSTEIN et al. 1999), prior to development of a pilot-plant for $\mathrm{Hg}$ (II) removal using this technology (WAGNER-DOBLER et al. 2000). In the latter study, a 700-liter reactor was packed with pumice granules of particle size 4-6 $\mathrm{mm}$ and inoculated with seven mercury resistant Pseudomonas species. Acidic wastewater from a chloralkali factory was neutralized and amended with sucrose and yeast extract prior to introduction into the bioreactor. Concentrations of up to $10 \mathrm{mg} / 1 \mathrm{Hg}$ were successfully treated with a removal efficiency of $95 \%$, although influent spikes above this concentration had a deleterious (if reversible) effect on the reactor performance. When operated in combination with an activated carbon filter, which also became colonized by bacteria, further removal of $\mathrm{Hg}$ to below $10 \mathrm{ug} / \mathrm{L}$ was reported. Very high loadings of $\mathrm{Hg}$ were retained in the reactor, conservatively estimated at $31.5 \mathrm{Kg}$ for the 700 -liter vessel.

Long-term performance of the reactors has been studied, with no loss of the entrapped $\operatorname{Hg}(0)$ from the system over 16 months (VON CANSTEIN et al. 2001). Although the reactors were sensitive to mechanical and physical stresses (e.g. shear from gas bubbles or increased temperature over $41^{\circ} \mathrm{C}$ ), the system seems robust and able to adjust to elevated $\operatorname{Hg}(\mathrm{II})$ 
concentrations (up to $7.6 \mathrm{mg} / \mathrm{L}$ ) within several days (VON CANSTEIN et al. 2001). With a continuous selection pressure for mercury resistance, a stable and highly active mercuryreducing microbial community is established within the bioreactors; confirmed using PCR-based techniques targeting the intergenic spacer region of 16S-23S rDNA, and a functional gene target for $\mathrm{Hg}(\mathrm{II})$ reduction, merA (VON CANSTEIN et al. 2001). The performance of the reactor system has also been studied in response to the oscillation of the mercury concentration in the bioreactor inflow (VON CANSTEIN et al. 2002). At low mercury concentrations, maximum $\mathrm{Hg}$ (II) reduction occurred near the inflow at the bottom of the bioreactor. At higher concentrations, the zone of maximum activity migrated to the upper horizons. Molecular analysis of the microbial communities showed an increasing microbial diversity along a gradient of decreasing mercury concentrations (VON CANSTEIN et al. 2002).

\subsection{CASE STUDY 3: EX SITU BIOREMEDIATION OF METALS USING SULFATE- REDUCING BACTERIA}

The ability of sulfate-reducing bacteria to precipitate metals as insoluble metal sulfides has been used by Paques BV of the Netherlands (www.paques.nl) in ex situ bioreactors for the treatment of metal-contaminated water. The patented reactor configurations, marketed under the registered trademark "Thiopaq ${ }^{\circledR} "$ can also be adapted to treat other waste streams containing sulfur compounds including hydrogen sulfide.

Early development work focused on the Budel Zinc B.V. refinery at Budel-Dorplein in the Netherlands . Over 200,000 tons of zinc are produced annually at the refinery, which has been operated since 1973. However, zinc was refined by various companies at this site for more than 100 years, resulting in contamination of soil and groundwater with heavy metals and sulfate. In 1992 Paques designed and installed a system to treat water extracted from strategically located wells around a geohydrological containment system installed to protect local drinking water supplies (BARNES et al. 1994). The bioreactor system is shown in Figure 9A, with a flow sheet of the process shown in Figure 9B. In the first stage, water is passed to an anaerobic bioreactor containing sulfate-reducing bacteria that couple the oxidation of ethanol to the reduction of sulfate to sulfide. This leads to the precipitation of insoluble metal sulfides.

$\mathrm{H}_{2} \mathrm{~S}+\mathrm{ZnSO}_{4} \rightarrow \mathrm{ZnS}$ (precipitate) $+\mathrm{H}_{2} \mathrm{SO}_{4}$ 
Excess toxic sulfide is then oxidized to elemental sulfur in an aerobic reactor, and tilted plate settlers (TPLS) and sand filters are used as final polishing steps to remove solids. Metal sulfides and elemental sulfur are returned to the plant for metal recovery and sulfuric acid production respectively. Performance of this system is summarized in Table 4.

Since 1999, this type of technology has also been employed by Budel-Dorplein to treat process streams containing sulfate and zinc produced by the conventional roast-leach-electrowin process operated at this site. These streams were previously treated conventionally by neutralization with lime, resulting in the production of 18 tons/day gypsum. However, recent legislation prohibited further production of solid residues from July 2000. The high rate Thiopaq ${ }^{\circledR}$ biological sulfate reduction bioreactor, supplied with hydrogen as the electron donor was, however, able to convert zinc and sulfate into zinc sulfide (10 tons/day), which is recycled at the refinery.

Paques have also used THIOPAQ ${ }^{\circledR}$ to remove metals from an alkaline slag dump leachate at Kovohute Pribram lead waste recycling facility in the Czech Republic. An alkaline carbonate buffered sodium sulfate leachate, containing lead, zinc, tin, and high concentrations of arsenic and antimony is treated using hydrogen sulfide that is produced in a separate bioreactor from the reduction of elemental sulfur (WEIJMA et al. 2002). Ethanol is used as the electron donor for sulfur reduction. The hydrogen sulfide is passed into gas-liquid contractors where it reacts with leachate that has been acidified by waste battery acid, leading to the precipitation of arsenic and antimony as sulfides. In a second stage, the remaining metal sulfides are precipitated at neutral $\mathrm{pH}$. Paques report that this technology significantly out-performs lime treatment due to the lower solubility of metal sulfides as opposed to hydroxides.

\subsection{CASE STUDY 4: IN SITU URANIUM BIOREMEDIATION THROUGH BIOREDUCTION}

Laboratory studies of uranium-contaminated aquifer sediment collected from uranium mill tailings remedial action (UMTRA) sites in Colorado and New Mexico indicated that acetate 
addition stimulated anaerobic conditions and the loss of soluble U(VI) from solution (FINNERAN et al. 2002). Loss of soluble U(VI) occurred in live sediments only, coincident with Fe(II) production and prior to observed losses of sulfate (FINNERAN et al. 2002). These results are consistent with the loss of $\mathrm{U}(\mathrm{VI})$ from solution occurring under stimulated $\mathrm{Fe}(\mathrm{III})$-reducing conditions. More detailed analyses of the stimulated microbial community using 16S rDNAbased techniques revealed that the stimulated loss of U(VI) from solution occurred as the microbial community shifted towards organisms known to reduce both Fe(III) and U(VI). In these studies Geobacteraceae, known Fe(III)- and U(VI)-reducing, microorganisms were greatly enriched (up to $40 \%$ of the detected bacterial community) in sediments exhibiting a loss of soluble U(VI) relative to control sediment incubations (HoLmes et al. 2002). These results indicated that the addition of acetate to the subsurface of uranium-contaminated aquifers would result in the removal of soluble U(VI) from groundwater under Fe(III)-reducing conditions consistent with the know ability of Geobacteraceae to reduce soluble U(VI) to insoluble U(IV) (Figure 10). This hypothesis was tested at the field scale at the Old Rifle UMTRA site in Rifle, Colorado (NABIR 2004).

Acetate addition to the subsurface of the Old Rifle UMTRA site stimulated the loss of U(VI) from groundwater. A test plot consisting of an acetate injection gallery composed of 20 injection wells in tow offset rows of 10 wells each and a total of 18 monitoring wells were installed within a $16 \mathrm{~m}$ x $24 \mathrm{~m}$ portion of the Old Rifle site (Figure 11) (ANDERSON et al. 2003). Initial groundwater sampling indicated $\mathrm{U}(\mathrm{VI})$ concentrations of approximately 0.4 to $1.4 \mu \mathrm{M}$, well above the established UMTRA contaminant limit of $18 \mu \mathrm{M}$ for this site. A sodium acetate solution $(100 \mathrm{mM})$ containing a bromide tracer $(10 \mathrm{mM} \mathrm{KBr})$ was prepared from site groundwater, sparged with nitrogen gas and stored anaerobically under nitrogen pressure $(0.1$ atm) within a stainless steel tank (2081 liters capacity) housed within a storage shed erected on site. Acetate solution flowed from the storage tank to a manifold spanning the entire width of the injection gallery to 60 injection ports within the 20 injection wells (3 ports per well) delivering acetate to three different depths within the saturated subsurface (ANDERSON et al. 2003). Each injection port was fitted with a flow meter set to provide acetate to the subsurface at a rate of 1-3 $\mathrm{ml} / \mathrm{min}$, which corresponded to a calculated volume addition to the aquifer of $1-3 \%$ per day (in situ acetate concentration 1-3 mM). Upon the initiation of acetate injection, soluble uranium 
concentrations decreased rapidly within the monitoring well field resulting in removal percentage averaging $70 \%$ of initial concentrations over a period of approximately 50 days. Loss of soluble U(VI) occurred coincident with the arrival of acetate, the production of Fe(II) and prior to any observed loss of sulfate. Furthermore, 16S rDNA-based analyses of the groundwater indicated a microbial community greatly enriched in Geobacteraceae, up to $89 \%$ of the detected bacterial community. Phospholipid fatty acid (PLFA) analyses of groundwater using "Geobacteraceae-specific" lipids also indicated an increase in Geobacter biomass. These results are consistent with the previous laboratory studies indicating a stimulated removal of soluble $\mathrm{U}(\mathrm{VI})$ from groundwater via the in situ stimulation of $\mathrm{Fe}(\mathrm{III})$ - and U(VI)-reducing Geobacteraceae (ANDERSON et al. 2003; FINNERAN et al. 2002; HoLMES et al. 2002).

Metal-reducing conditions were not sustained within the Old Rifle site over 50 days, and it was thought that acetate-oxidizing sulfate-reducing bacteria became dominant when Fe(III) was depleted. In the vicinity of the injection gallery and the terminal electron accepting process shifted to sulfate reduction. Indeed, a complete loss of acetate (limiting under sulfate-reducing conditions in this aquifer) was accompanied by a nearly stoichiometric loss of sulfate from the groundwater. Analyses of the microbial community detected within the groundwater also indicated a shift from a community dominated by Fe(III)-reducing organisms to a community dominated by organisms known to reduce sulfate, i.e. Desulfobacteraceae (ANDERSON et al. 2003). The results stress the importance of maintaining metal reduction within the subsurface or encouraging the growth and activity of sulfate-reducing bacteria capable of U(VI) reduction; acetate-oxidizing sulfate-reducing bacteria have not been shown to reduce U(VI), although there is ample evidence that lactate-oxidizing sulfate-reducing bacteria are able to reduce U(VI) using lactate or hydrogen as electron donors (LOVLEY and PHILliPs 1992; LOVLEY et al. 1993). Thus, addition of these electron donors to the subsurface may stimulate U(VI) reduction in situ.

\section{BIOACCUMULATION AND BIOSORPTION}

Bioaccumulation and biosorption strategies for remediation of metals and radionuclide contaminated soil are based on the ability of bacteria and plants to concentrate metals within the cells at concentrations 1000s of times higher then the ambient concentrations. By forming phosphate-metal, organo-metal or metal-sulfide complexes, they become insoluble or at least not 
bioavailable to the target risk group, i.e. less toxic. Biosolids applications and phytoextraction have proven to be possible applications of this approach.

\subsection{USE OF BIOSOLIDS FOR TREATMENT OF METAL CONTAMINATED SOILS}

\subsubsection{BIOSOLIDS FOR REMEDIATON OF METAL CONTAMINATED SOILS}

The conventional remedial approach to metal contaminated soils within the US EPA Superfund program involves stabilization and replacement of the soil with clean material or capping the soil with an impermeable material to reduce potential exposure to the contaminants. Standardized tests exist to evaluate the contaminated soils as well as to measure the success of the remedial action, but the tests are largely engineering based and do not consider ecosystem function. Tests commonly used include measures of total metal concentrations and of the potential for metals to leach into groundwater (i.e. toxicity Characteristic Leaching Procedure, SW-846 Method 1311, Multiple Extractions with different molar acid solutions). Human exposure to contaminated groundwater is the driving factor both in identifying contaminants of concern as well as in setting appropriate concentration limits (National Research Council, 2003).

Alternative remedial technologies are currently being developed that involve leaving the contaminated materials in place and using soil amendments to reduce the bioavailability to humans (BROWN et al. 2004; RYAN et al. 2004). The use of municipal biosolids for restoration of disturbed lands is well documented (SOPPER 1993). Recent studies show that amending soils with municipal biosolids and lime to reduce the bioavailability of contaminants, restores ecological function to soil to enable a vegetative cover for large-scale metal contaminated sites (BASta et al. 2001; Brown et al. 2003a; Brown et al. 2003b; Conder et al. 2001; Li et al. 2000).

\subsubsection{BIOAVAILABILITY}

While conventional extraction tests have been used to evaluate the success of in situ technologies, additional assays are necessary to measure restoration of ecosystem function. In particular, bioavailability has to be more broadly considered to include a range of ecological receptors and relevant pathways (NATIONAL_RESEARCH_COUNCIL 2003). 
Several procedures have been developed to measure the bioavailable, rather than total, fraction of contaminants in soils and sediments and these are generally based on the exposure pathway for the most sensitive ecological receptor. In many cases, toxicity is the defined endpoint. For example, soil extracts are routinely used to determine the phytoavailable fraction of total nutrient concentrations in soils (MCLAUGHLIN et al. 2000; SPARKS et al. 1996). In cases of contaminated soils, extracts have been altered to better mimic the behavior of plants in these environments. Diffusive gradients in thin films have been found to better mimic soluble metal bioavailability for assessing the potential for phytotoxcity (SAUVE 2002; ZHANG et al. 2001). Extracts have also been correlated with reductions in microbial activity, as measure by microbial lux biosensors (SHAW et al. 2000; VULKAN et al. 2000).

Direct toxicity tests and animal feeding trails are also used. Earthworm mortality has been used as a measure of the effectiveness of soil amendments to reduce bioavailability in mime tailings (CONDER et al. 2001). Both in vivo and in vitro extracts have been used to predict the bioavailability of soil $\mathrm{Pb}$ to humans (RUBY et al. 1996). In each case, the test was developed to focus on a particular endpoint or receptor. None of the tests attempts to evaluate the collective ecosystem function.

\subsubsection{ECOSYSTEM FUNCTIONING}

Methods to assess ecosystem function are rare. Techniques have been developed to assess the health of the soil microbial population, including measure of soil function through respiration, $\mathrm{N}$ cycling, and ability to utilize added substrates (CELA and SUMNER 2002; CHANG and Broadbent 1982; McGrath 2002; Sauve 2002). One example is the Biolog extraction (KeLLY and TATE 1998), which attempts to evaluate the functionality of the soil microbial population through its ability to utilize a range of carbon sources. The procedure has been criticized for difficulty of interpretation, i.e. organism presence can falsely suggest a robust microbial community, and the ability of different groups of microbes to utilize the same substrates (NATIONAL_RESEARCH_COUNCIL 2003). Other tests assess bioavailability of contaminants by measuring the reactions of single types of organisms to exposure to remediated soils (GEEBELEN et al. 2003). 
For the amended tailings in Leadville, an alternative testing protocol was developed. In addition to conventional engineering criteria, standard principles of ecological function were used to develop a series of tests to assess amendment impacts on ecosystem function. For example, the ability of the system to decompose organic matter and recycle nutrients can indicate the stability of the restored system. In addition, examining the health of, and contaminants from, the amended soil through the food chain.

From the studies on the use of biosolids to treat metal contaminated soil, it is clear that conventional tests alone will not provide an appropriate assessment of the ability of an in situ amendment to restore ecosystem function to metal contaminated soils. These tests need to be combined with analyses of ecosystem function and measures of the potential for contaminated transfer through the food chain.

\subsection{CASE STUDY 5: ECOSYSTEM FUNCTION IN ALLUVIAL TAILINGS AFTER BIOSOLIDS AND LIME ADDITION}

Municipal biosolids and agricultural limestone were incorporated into the surface of alluvial highly acidic, metal contaminated mine tailings in Leadville, Co in 1998 (Brown et al. 2005). Amended sites were seeded, and a plant cover subsequently established. A range of chemical and biological parameters were measured over time to determine if treatment was sufficient to restore ecosystem function. An uncontaminated upstream control (UUC), a contaminated vegetated area (CVA), and soils collected from the tailings deposits prior to amendment addition were used for comparison. Standard soil extracts showed decreases in extractable $\mathrm{Pb}, \mathrm{Zn}$, and $\mathrm{Cd}$ in the amended soils. Increased $\mathrm{CO}_{2}$ evolution, reduced $\mathrm{N}_{2} \mathrm{O}$ and elevated $\mathrm{NO}_{3}{ }^{-}$in the amended tailings, indicated an active microbial community (Table 5). Levels of $\mathrm{CO}_{2}$ and $\mathrm{NO}_{3}{ }^{-}$ were elevated in comparison to the CVA and the UUC. Rye grass (Lolium perenne) and earthworm (Eisenia foetida) survival, as well as metal uptake values were similar in amended tailings to a laboratory control soil. Rye grass and worms in unamended tailings died. Field plant diversity was lower in amended areas than in CVA or UUC, with a higher percentage of the vegetative cover consisting of grasses. Small mammal analysis showed a low potential for elevated body $\mathrm{Cd}$ and $\mathrm{Pb}$ in the amended tailings. A re-entrainment study using fathead 
minnows (Pimephales promelas) showed no danger for re-suspended amended tailings, survival of fish was similar to the laboratory control. Data suggest (Figure 12) that ecosystem function has been restored to the amended tailings, but these systems are not yet in equilibrium (BROWN et al. 2005).

\subsection{CASE STUDY 6: IN SITU SOIL TREATMENTS TO REDUCE THE PHYTO- AND BIOAVAILABILITY OF LEAD, ZINC, AND CADMIUM}

A study was established near a former $\mathrm{Zn}$ and $\mathrm{Pb}$ smelter to test the ability of soil amendments to reduce the availability of $\mathrm{Pb}, \mathrm{Zn}$, and $\mathrm{Cd}$ in situ. Soil collected from the field was amended in the lab with $\mathrm{P}$ added as $1 \% \mathrm{P}-\mathrm{H}_{3} \mathrm{PO}_{4}$, biosolids compost added at $10 \%$ (referred to hereafter as "compost"), and a high-Fe by-product (referred to hereafter as "Fe") + P-triple superphosphate (TSP) $(2.5 \% \mathrm{Fe}+1 \% \mathrm{P}$-TSP) and incubated under laboratory conditions at a constant soil $\mathrm{pH}$. Changes to $\mathrm{Pb}$ bioavailability were measured with an in vitro test and a feeding study with weanling rats. Field-amended and incubated soils using these plus addition treatments was evaluated using the in vitro extraction and tall fescue (Festuca arundinacea Schreb. cv. Kentucky-31) metal concentration. Reductions were observed across all parameters but were not consistent. In the feeding study, the $1 \% \mathrm{P}_{-} \mathrm{H}_{3} \mathrm{PO}_{4}$ treatment caused the greatest reduction in vitro extractable $\mathrm{Pb}$ from field samples $(\mathrm{pH} 2.2)$ with a measured reduction of $66 \%$, while the compost treatment has a $39 \%$ reduction and the $2.5 \% \mathrm{Fe}+1 \% \mathrm{P}$-TSP treatment a $50 \%$ reduction. The in vitro extraction $(\mathrm{pH} 1.5)$ run on field samples showed no reduction in the compost or Fe treatments. The $1 \% \mathrm{P}-\mathrm{H}_{3} \mathrm{PO}_{4}$ treatment was the most effective at reducing plant $\mathrm{Pb}, \mathrm{Zn}$, and $\mathrm{Cd}$ (BROWN et al. 2004).

\subsection{CASE STUDY 7: USING MUNICIPAL BIOSOLIDS IN COMBINATION WITH OTHER RESIDUALS TO RESTORE METAL-CONTAMINATED MINING AREAS}

High metal waste materials from historic mining at the Bunker Hill, Idaho (ID) Superfund site was amended with a range of materials including municipal biosolids, woody debris, pulp and paper sludge, and compost (BROWN et al. 2003b). The existing soil or waste material elevated metal concentrations with total $\mathrm{Zn}, \mathrm{Pb}$ and $\mathrm{Cd}$ ranging from 6000 to 14700,2100 to 27000 and 9 to $28 \mathrm{mg} \mathrm{kg}^{-1}$, respectively. Surface application of certain amendments including biosolids 
mixed with wood ash resulted in significant decreases in subsoil acidity as well as subsoil extractable metals. This mixture was sufficient to restore a plant cover to the contaminated areas. At the Bunker Hill site, a surface application of high N biosolids (44 or 66 tons ha ${ }^{-1}$ ) in combination with wood ash $\left(220\right.$ tons $\left.\mathrm{ha}^{-1}\right)$ was able to restore a vegetative cover to the metal contaminated of the vegetation indicated that plans were within normal concentrations for the 2 years that data were collected. Surface application of amendments was also able to reduce $\mathrm{Ca}$ $\left(\mathrm{NO}_{3}\right)_{2}$ extractable $\mathrm{Zn}$ in the subsoil from about $50 \mathrm{mg} \mathrm{kg}^{-1}$ in the control to less than $4 \mathrm{mg} \mathrm{kg}^{-1}$ in two treatments. Use of conventional amendments including lime alone and microbial stimulants were not sufficient to support plant growth. These results indicate that surface application of biosolids in combination with other residuals is sufficient to restore a vegetative cover to high metal mine wastes (BROwN et al. 2003b).

\subsection{CASE STUDY 8: IN SITU REMEDIATION AND PHYTOEXTRACTION OF METALS FROM HAZARDOUS CONTAMINATED SOILS}

Mining and smelting of $\mathrm{Pb}, \mathrm{Zn}$, and $\mathrm{Cd}$ ores have caused widespread soil contamination in many countries. In locations with severe soil contamination, and strongly acidic soil or mine waste, ecosystems are devastated. Research has shown that $\mathrm{Zn}$ phytotoxicity, $\mathrm{Pb}$-induced phosphate deficiency, $\mathrm{Cd}$ risk through uptake by rice or tobacco, and $\mathrm{Pb}$ risk to children, livestock or wildlife which ingest soil are the common adverse environmental effects at suck contaminated sites. Improved understandings of soil metal risks to the environment have been developed which examine risk to all possible exposed organisms through soil, plants, animals, or water exposures.

Soil Cd risk to food-chains only occurs when $\mathrm{Cd}$ is present at the usual 0.005-0.02 ratio to $\mathrm{Zn}$ in the contaminated soil, only rice and tobacco allow $\mathrm{Cd}$ to be transferred from the soil in amounts which can harm humans over their lifetime. $\mathrm{Zn}$ inhibits plant uptake of $\mathrm{Cd}$ and inhibits intestinal absorption of $\mathrm{Cd}$, protecting animals from $\mathrm{Cd}$ in most situations. $\mathrm{Pb}$ risk to children or other highly exposed mammals results from ingestion of the contaminated soil, and absorption of $\mathrm{Pb}$ from the soil into the blood where adverse health effects occur at 1.0-to-1.5 $\mu \mathrm{g} \mathrm{Pb} / \mathrm{L}$ blood. Soil $\mathrm{Pb}$ has much lower bioavailability than water $\mathrm{Pb}$, and if ingested with food it has even lower 
bioavailability. Research has shown that if high phosphate levels are added to $\mathrm{Pb}$ contaminated soils, an extremely insoluble $\mathrm{Pb}$ compound, chloropyromorphite, is formed in soils from all known chemical species of $\mathrm{Pb}$ which occurs in contaminated soils. It had earlier been learned that adding adsorbents such as hydrous $\mathrm{Fe}$ oxides and phosphate to $\mathrm{Pb}$ contaminated soils inhibited $\mathrm{Pb}$ uptake by crops, and combined with the evidence that these materials could reduce the bioavailability of soil $\mathrm{Pb}$ to children, feeding tests were conducted with rats and pigs in several laboratories (CHANEY et al. 1999).

A new approach to remediation of severely disturbed $\mathrm{Pb} / \mathrm{Zn} / \mathrm{Cd}$ contaminated soils has been developed which uses mixtures of limestone equivalent from industrial byproducts such as wood ash (to make soil calcareous and prevent $\mathrm{Zn}$ phytotoxicity), phosphate and Fe from biosolids and by-products (to precipitate $\mathrm{Pb}$ and with $\mathrm{Fe}$, increase $\mathrm{Pb}$ adsorption), organic- $\mathrm{N}$ from biosolids and manures and other beneficial components which correct the infertility of contaminated and eroded soils. Composting can stabilize the organic matter and slow $\mathrm{N}$ release to allow higher test locations where this approach was tested (Palmerton in PA; Bunker Hill in ID; Leadville in CO in US, and Katowice, Poland). All plants tested were readily grown on the amended soil even when soils contained over $1 \% \mathrm{Zn}$ and $1 \% \mathrm{~Pb}$. Plant analysis indicates that these plants may be consumed safely by wildlife and livestock, although soil ingestion should be minimized at such sites. Although mining and smelting contamination has caused severe environmental harm in many locations, this method of soil metal remediation allows effective and persistent remediation at low cost, and should be applied to prevent further dispersal of the contaminated soil materials at many locations.

The potential use of metal hyperaccumulator plants to phytoextract soil metals is a new method of remediation under development. Combining improved cultivars of these accumulator plants, agronomic management practices to maximize yield and metal accumulation, burning the biomass to generate power, and recovery of metals from the ash appear to offer an economic technology compared to soil removal and replacement (CHANEY et al. 1999).

\section{BIODEGRADATION OF CHELATORS AND BIOSURFACTANTS}

A number of chelators have been used to increase the solubility of metals and radionuclides and 
facilitate desired chemical or microbial reactions. However, when the chelators are disposed of with the metals/radionuclides or were disposed of as the chelator-metal complex it makes the metal more mobile in the environment and potentially more toxic. The US Department of Energy used a number of chelators in nuclear production processes some of which are readily biodegradable and others that are fairly recalcitrant (NABIR 2004). Citric acid, nitrilo acetic acid (NTA), and ethylene diamine disuccinate (EDDS) are relatively biodegradable; while ethylene diamine tetraacetate (EDTA) is much more difficult to biodegrade (MEERS et al. 2005). Several studies have shown that EDTA is biodegradable, but it does tend to persist longer in the environment than the others (BOHUSLAVEK et al. 2001; GORBY et al. 1998). We are unaware of any applications that promoted chelator degraders for bioremediation of a contaminated site, but it certainly would be a possibility, especially using a bioaugmentation application ex situ. Biodegradation of chelators is also of interest for phytoextraction, since the chelator promotes the uptake of the metal in the plant (MeERs et al. 2005). Persistence of chelator in the rhizosphere could lead to groundwater contamination down gradient. Several compounds that are naturally produced by microbes in the soil have been found to be chelators. Thus, it raises the possibility that stimulation of certain microbial populations could lead to the production of chelators and increase metal mobility, either a desirable or undesirable outcome, depending on whether you are trying to mobilize or immobilize the metal/radionuclide.

Bacteria can also produce biosurfactants, which combine complexation activity with physical sequestration of the complexed ions. As a surface-active agent, the biosurfactant can concentrate metals from the soil into critical aggregates that will form at critical micelle concentrations a 50 $\mathrm{nm}$ particle that can escape most filtration processes (MEERs et al. 2005). Biosurfactants would only be used as a strategy for mobilization of metals combined with phytoextraction or pump and treat.

\section{BIOLOGICALLY-ASSISTED SOIL WASHING AND BIOLEACHING}

Biologically-assisted soil washing for metal remediation can occur when indigenous microbes are stimulated via the washing process by adding specific electron donors or electron acceptors that will encourage bacteria that produce acids or surfactants. Microbial leaching is a process of 
promoting leaching of metals from rock by chemolithotrophs that oxidize iron and sulfides, generating sulfuric acid and thus releasing the associated metals (BRIERLEY 1982). Bioleaching for copper is one of the oldest known biotechnology applications. One of the earliest records of the practice of leaching is from the island of Cyprus. Galen, a naturalist and physician reported in $\mathrm{AD} 166$ the operation of in situ leaching of copper. Surface water was allowed to percolate through the permeable rock, and was collected in amphorae. In the process of percolation through the rock, copper minerals dissolved so that the concentration of copper sulfate in solution was high. The solution was allowed to evaporate until copper sulfate crystallized. Pliny (23-79 AD) reported that a similar practice for the extraction of copper in the form of copper sulfate was widely practiced in Spain. This same process also causes acid mine drainage from mining waste and abandoned mines. The $\mathrm{pH}$ of acid mine waste can get down less than 1.0 and generate temperatures in excess of $50^{\circ} \mathrm{C}$. Recently the Iron Mountain mine in California acid mine drainage has been the sight of some ground breaking research in metagenome analysis and metaproteome analysis (RAM et al. 2005; TYSON et al. 2004). Because of the extreme nature of this environment they were able to sequence and sort out the genomes of all of the dominant microbes present without ever culturing them, even more recently the same group has analyzed directly all the proteins present to determine the relationship between the bacteria in this community (RAM et al. 2005). This promises new insights as to how this community functions and the interdependencies of metabolic pathways and biogeochemistry of this ecosystem.

$\mathrm{Zn}, \mathrm{Au}, \mathrm{Co}$ and a variety of other metals are mined using bioleaching usually with an irrigation leach or a stirred tank biooxidation (Figure 13). Indeed, over $20 \%$ of the world's copper is produced in this way. Bioleaching can also generate a significant waste, e.g. final gold extraction process uses cyanide. The cyanide/metal waste liquor that remains is then treated in a bioreactor to degrade the cyanide (BRIERLEY 1982; BRIERLEY 1990).

Bioleaching has been used in Germany for removal of metals from dredged sediments (SEIDEL et al. 2004). About $62 \%$ of the $\mathrm{Zn}, \mathrm{Cd}, \mathrm{Ni}, \mathrm{Co}$, and Mn were removed from the sediment in 120 days if the sediment was oxic and of good permeability. However, only $9 \%$ was removed when the sediment were freshly dredged and anoxic. Similar processes have been reported in the Netherlands and Switzerland (TiCHY et al. 1998). 


\section{VOLATILIZATION}

Biovolatilization occurs with several metals that undergo methylation when they are taken up by the plant or microbial cell. Unfortunately, this makes the metal, e.g. $\mathrm{Hg}$ and $\mathrm{Se}$, many times more toxic than the elemental form. Thus, the main worry of regulators and stakeholders has been that the methylated metal would accumulate in the food chain and potentially be spread over a wider area around the treatment zone unless fugitive air emissions were trapped. The central valley of California has a notorious problem with Se buildup in ponds in wetlands in the area, which have proven to be toxic for local wildlife. Studies by Terry et al. ((DE SouZA et al. 2001)) and Frankenberger et al. (Frankenberger and Arshad 2001; Frankenberger and KARLSON 1994; FrANKENBERGER and KARLSON 1995) demonstrated that from 30 to $70 \%$ of the Se coming into the wetlands are volatilized. Microalgae and bacteria were shown to be responsible in a number of studies that added fungicides and bacteriocides to the wetlands water. The fungicides had no effect on dimethylselinite releases, while the bacteriocides greatly reduced the rate of dimethylselinite production. While a number of investigators have proposed volatilization as a bioremediation strategy for these ponds and wetlands because it is as safe as anything else proposed and lot cheaper, the regulators, and stakeholders have not yet funded a full-scale treatment facility.

\section{TREATMENT TRAINS AND NATURAL ATTENUATION}

Treatment trains or multiple treatment approaches are clearly the best way to keep costs down and remediate a large plume as quickly as possible. Unfortunately, there are few documented field examples of this, especially those that incorporate a physical/chemical treatment followed by biostimulation, passive bioremediation, and finally natural attenuation. Our understanding of reduction/oxidation biogeochemistry in the subsurface is still too primitive to have good predictive models of how even metals like $\mathrm{Cr}$ and $\mathrm{U}$ would behave on the long-term. Thus, a monitored natural attenuation, while feasible, is practically unheard of. The following two case studies show multiple component systems and how they were linked together to solve a problem and reduce cost, and improve efficiency. 
7.1 CASE STUDY 9: ALGAL HIGH RATE POND COMBINATIONS FOR REMOVAL OF SE IN AGRICULTURE DRAINAGE WATER

Monthly Maximum Discharge Limits (MMDL) have been established for selenium in irrigation drainage by the State of California and the U.S. Environmental Protection Agency following observations of avian teratogenesis at the Kesterson Reservoir in the San Joaquin Valley of California (GREEN et al. 2003). As a result of these and other adverse effects, farmers and drainage districts on the western side of the San Joaquin Valley must reduce selenium concentrations in irrigation, drainage discharged to the San Joaquin River (GREEN et al. 2003). Drainage treatment will be required in the near future to meet existing MMDL and future Total Maximum Discharge Limits (TMDL) for the San Joaquin River.

A pilot-scale 0.4-hectare Algal Bacterial Selenium Removal (ABSR) Facility was designed and constructed at the Panoche Drainage District in 1995 and 1996 using the Advanced Integrated Wastewater Pond Systems(R) or AIWPS(R) Technology (GREEN et al. 2003). Each of two physically identical systems combined a Reduction Pond (RP) with a shallow, peripheral algal High Rate Pond (HRP). A Dissolved Air Flotation (DAF) unit and a slow sand filter were used to remove particulate selenium from the effluent of each system. The two systems were operated under different modes of operation and the bacterial substrate varied in each system. Microalgae were harvested using DAF and used as a carbon-rich substrate for nitrate- and selenate-reducing bacteria. Mass removals of total soluble selenium of $77 \%$ or greater were achieved over a threeyear period. Nitrate and selenate were removed by assimilatory and dissimiliatory bacterial reduction, and nitrate was also removed by algal assimilation. The removal of particulate selenium increased the overall removal of selenium to over $90 \%$ and would allow farmers and drainage districts to discharge irrigation drainage in compliance with regulatory discharge limits. A full-scale system is currently under construction at the same site.

\subsection{CASE STUDY 10: IN SITU GROUNDWATER BIOREDUCTION OF U(VI) WITH} UPGRADIENT PRECONDITIONING USING FLUIDIZED BED BIOREACTOR

At the US Department of Energy Oak Ridge Y-12 Field Research Center, pilot scale test has been run for the last year to demonstrate the utility of a treatment train, both ex situ and in situ for treatment of groundwater with low $\mathrm{pH}(\sim 3.0)$, high nitrate $(11,000 \mathrm{ppm})$ and high uranium 
(10 $\mu \mathrm{MM}$ ) (see $\underline{\text { http://www.stanford.edu/group/evpilot/Reasearch/Oakridge/oakridgepics/ }}$ oakridgeintro.html). Since U(VI) cannot be reduced when high concentrations of nitrate are still present and the nitrate would potentially produce enough gas to plug the subsurface if enough electron donor was added to deplete the nitrate, it was decided to create a recirculation zone and remove a large part of the nitrate in the groundwater prior to adding enough electron donor to reduce the $\mathrm{U}(\mathrm{VI})$. The above ground system removes aluminum, calcium, and nitrate and then the $\mathrm{pH}$ is adjusted to $\sim 6.2$ to prevent the aluminum from co-precipitating the $U$ and other metals when the $\mathrm{pH}$ is adjusted, the water is then reinjected to establish an inner treatment zone and out protection loop. During the first 100 days of in situ biostimulation, the U(VI) concentration went from $10 \mu \mathrm{M}$ to less then $3 \mu \mathrm{M}$ in the groundwater. Microbial analysis of the groundwater indicated growth of denitrifiers, sulfate-reducing bacteria, and iron-reducing bacteria. Control of $\mathrm{pH} /$ carbonate levels is an engineering tool for the management of U(VI) bioavailability, to limit $\mathrm{U}(\mathrm{VI})$ escape from the treatment zone, and to prevent growth of methanogens, which interfere with U(VI) reduction (see http://www.lbl.gov/NABIR/generalinfo/annualmtg/ 05_ann_mtg_pstr1.html).

\section{SUMMARY}

Bioremediation of metals and radionuclides is a fairly new technology for waste site remediation, though bioleaching for metal recovery has been practiced for nearly 2,000 years. Since metals and radionuclides are not destroyed, but only transformed, it makes both in situ and ex situ strategies more difficult than organic compounds. This also makes the biogeochemistry (especially $\mathrm{Eh} / \mathrm{pH}$ ) much more critical for controlling the long-term stability and controlling the remediation process itself. Characterization, monitoring and development of a conceptual model are important to minimize errors and to develop sound functional design criteria for the remediation effort. Bioreduction has a field presence and is starting to show real promise, especially as it relates to immobilization strategies. Biooxidation and mobilization strategies could be a better long-term solution since it can be coupled with removal from the environment. However, our lack of knowledge about critical biogeochemistry is not providing confidence to the regulators and stakeholders. Bioaccumulation, biosorption, and biovolatilization have demonstrated utility especially with biosolids applications and phytoextractions. Unfortunately, 
all need more research to be widely practical since the exact mechanisms of biosolids applications are not understood and have not been adequately researched, they may involve sorption and reduction/oxidation, which could effect long-term stability of these sites. Phytoextraction suffers from being too slow and representing increase risk. The greatest problem with phytoextraction especially with highly toxic heavy metals and radionuclides is not that it won't work, but rather the secondary waste issues created by the metal containing biomass. Disposal costs and overall life cycle costs can keep this technology from reaching its full potential. Chelators and biosurfactants and their controlled biodegradation, will always be relegated to a small niche market. Biologically-assisted soil washing and bioleaching of metalcontaminated dredged sediments hold promise but are limited by organic co-contaminants and will probably require a treatment train, e.g. dredged sediment ripening before bioleaching, like is being done in several parts of Europe. Volatilization is unlikely to play a major role of bioremediation of any metal unless it is combined with fugitive air emission control methods. Treatment trains and natural attenuation are just getting started but will probably become dominant strategies over the next decade. Bioremediation of metals and radionuclides shows great promise but it will rarely be a stand-alone technology and it needs significant research investments. 


\section{REFERENCES}

Anderson R. T., Vrionis H. A., Ortiz-Bernad I., Resch C. T., Long P. E., Dayvault R., Karp K., Marutzky S., Metzler D. R., Peacock A., White D. C., Lowe M., and Lovley D. R. (2003) Stimulating the in situ activity of Geobacter species to remove uranium from the groundwater of a uranium-contaminated aquifer. Appl. Environ. Microbiol. 69(10), 58845891.

Barnes L. J., Scheeren P. J. M., and Buisman C. J. N. (1994) Microbial Removal of Heavy Metals and Sulfate from Contaminated Groundwaters. Emerging Technology for Bioremediation of Metals, 38-49.

Basta N. T., Gradwohl R., Snethen K. L., and Schroder J. L. (2001) Chemical immobilization of lead, zinc, and cadmium in smelter-contaminated soils using biosolids and rock phosphate.j. Environ. Qual. 30(4), 1222-1230.

Bohuslavek J., Payne J. W., Liu Y., Bolton H., and Xun L. Y. (2001) Cloning, sequencing, and characterization of a gene cluster involved in EDTA degradation from the bacterium BNC1. Appl. Environ. Microbiol. 67(2), 688-695.

Brierley C. L. (1982) Microbiological Mining. Scientific American 247, 44-53.

Brierley C. L. (1990) Bioremediation of metal-contaminated surface and groundwaters. Geomicrobiology Journal 8(3), 201-223.

Brown S., Chaney R., Hallfrisch J., Ryan J. A., and Berti W. R. (2004) In situ soil treatments to reduce the phyto- and bioavailability of lead, zinc, and cadmium. J. Environ. Qual. 33(2), 522-531.

Brown S., Sprenger M., Maxemchuk A., and Compton H. (2005) Ecosystem function in alluvial tailings after biosolids and lime addition. J. Environ. Qual. 34(1), 139-148.

Brown S. L., Chaney R., Halfrisch J., and Xue Q. (2003a) Effect of Biosolids Processing on Lead Bioavailability in an Urban Soil. J. Environ. Qual. 32, 100-108.

Brown S. L., Henry C. L., Chaney R., Compton H., and DeVolder P. S. (2003b) Using municipal biosolids in combination with other residuals to restore metal-contaminated mining areas. Plant and Soil 249(1), 203-215.

Cela S. and Sumner M. E. (2002) Critical concentrations of copper, nickel, lead, and cadmium in soils based on nitrification. Comm. in Soil and Plant Analysis 33(1-2), 19-30.

Chaney R. L., Brown S. L., Stuchynski T. I., Daniels W. L., Henry C. L., Li Y.-M., Siebelec G., Malik M., Angle J. S., Ryan J. A., and Compton H. (1999) Progress in Remediation of Soils Contaminated by Mining and Smelting of Lead, Zinc and Cadmium Using TailorMade Biosolids Mixtures and Composts. Innovative Clean-up Approaches: Investments in TEchnoogy Development, Results \& Outlook for the Future.

Chang F. H. and Broadbent F. E. (1982) Influence of trace metals on some soil nitrogen transformations. J. Environ. Qual. 11, 1-4.

Conder J. A., Lanno R. P., and Basta N. T. (2001) Assessment of metal availability in smelter soil using earthworms and chemical extractions. J. Environ. Qual 30, 1231-1237.

de Souza M. P., Amini A., Dojka M. A., Pickering I. J., Dawson S. C., Pace N. R., and Terry N. (2001) Identification and characterization of bacteria in a selenium-contaminated hypersaline evaporation pond. Appl. Environ. Microbiol. 67(9), 3785-3794. 
Finneran K. T., Anderson R. T., Nevin K. P., and Lovley D. R. (2002) Potential for Bioremediation of uranium-contaminated aquifers with microbial U(VI) reduction. Soil \& Sediment Contamination 11(3), 339-357.

Frankenberger W. T. and Arshad M. (2001) Bioremediation of selenium-contaminated sediments and water. Biofactors 14(1), 241-254.

Frankenberger W. T. and Karlson U. (1994) Soil-management factors affecting volatilization of selenium from dewatered sediments. Geomicrobiology Journal 12(4), 265-278.

Frankenberger W. T. and Karlson U. (1995) Volatilization of selenium from a dewatered seleniferous sediment - a field-study. Journal of Industrial Microbiology 14(3), 226-232.

Geebelen W., Vvan der Lelie D., Mench M., Carleer R., Chijsters H., and Vangronsveld J. (2003) Selected bioavailability assays to test the efficacy of amendment-induced immobilization of lead in soils. Plant and Soil 249, 217-228.

Gorby Y. A., Caccavo F., and Bolton H. (1998) Microbial reduction of cobalt(III)EDTA(-) in the presence and absence of manganese(IV) oxide. Environmental Science \& Technology 32(2), 244-250.

Green F. B., Lundquist T. J., Quinn N. W. T., Zarate M. A., Zubieta I. X., and Oswald W. J. (2003) Selenium and nitrate removal from agricultural drainage using the AIWPS (R) technology. Water Science and Technology 48(2), 299-305.

Hazen T. C. (1997) Bioremediation. In Microbiology of the Terrestrial Subsurface (ed. P. A. a. D. Haldeman), pp. 247-266. CRC Press.

Holmes D. E., Finneran K. T., O'Neil R. A., and Lovley D. R. (2002) Enrichment of members of the family Geobacteraceae associated with stimulation of dissimilatory metal reduction in uranium-contaminated aquifer sediments. Appl. Environ. Microbiol. 68(5), 2300-2306.

Kelly J. J. and Tate R. L. (1998) Use of BiOLOG for the analysis of microbial communities from zinc-contaminated soils. J. Environ. Qual. 27, 600-608.

Li Y., Chaney R., Siebielec G., and Kershner B. A. (2000) Response of four turfgrass cultivars to limestone and biosolids compost amendment of a zinc and cadmium contaminated soil at Palmerton, PA. J. Environ. Qual. 29, 1440-1447.

Loffler F. E., Sun Q., Li J., and Tiedje J. M. (2000) 16S rRNA Gene-Based Detection of Tetrachloroethene-Dechlorinating Desulfuromonas and Dehalococcoides Species. Appl. Environ. Microbiol. 66(4), 1369-3445.

Lovley D. R. and Phillips E. J. P. (1992) Reduction of uranium by Desulfovibrio desulfuricans. Appl. Environ. Microbiol. 58(3), 850-856.

Lovley D. R., Widman P. K., Woodward J. C., and Phillips E. J. P. (1993) Reduction of uranium by cytochrome c3 of Desulfovibrio vulgaris. Appl. Environ. Microbiol. 59(11), 35723576.

McCullough J., Hazen T. C., Benson S. M., Metting F. B., and Palmisano A. C. (1999) Bioremediation of Metals and Radionuclides. What it is and how it works., pp. 58. LBNL.

McGrath S. P. (2002) Critical Metals. Society of Environmetnal Toxicology and Chemistry.

McLaughlin M., Zarcinas B. A., Stevens D. P., and Cook N. (2000) Soil testing for heavy metals. Commun. Soil Sci. Plant Anal 31, 1661-1700.

Meers E., Ruttens A., Hopgood M. J., Samson D., and Tack F. M. G. (2005) Comparison of EDTA and EDDS as potential soil amendments for enhanced phytoextraction of heavy metals. Chemosphere 58(8), 1011-1022.

NABIR. (2004) Bioremediation of Metals and Radionuclides. What it is and how it works. 2nd Ed. (ed. T. C. Hazen), pp. 74. LBNL. 
National_Research_Council. (2003) Bioavailability of Contaminants in Soils and Sediments. National Academy of Sciences.

Plaza G., Ulfig K., Hazen T. C., and Brigmon R. L. (2001) Use of molecular techniques in bioremediation. Acta Microbiol Pol 50(3-4), 205-18.

Ram R. J., VerBerkmoes N. C., Thelen M. P., Tyson G. W., Baker B. J., Blake Ii R. C., Shah M., Hettich R. L., and Banfield J. F. (2005) Community Proteomics of a Natural Microbial Biofilm. Science, 1109070.

Ruby M. V., Davis A., Schoof R., Eberle S., and Sellstone C. M. (1996) Estimation of lead and arsenic bioavailability using a physiologically-based extraction test. Environmental Science \& Technology 30(2), 422-430.

Ryan J. A., Scheckel K. G., Berti W. R., Brown S. L., Casteel S. W., Chaney R. L., Hallfrisch J., Doolan M., Grevatt P., Maddaloni M., and Mosby D. (2004) Reducing children's risk from lead in soil. Environ. Sci. and Technol. 38(1), 18A-24A.

Sauve S. (2002) Speciation of metals in soil. Society of Environmental Toxicology and Chemistry.

Seidel H., Loser C., Zehnsdorf A., Hoffmann P., and Schmerold R. (2004) Bioremediation process for sediments contaminated by heavy metals: Feasibility study on a pilot scale. Environ. Sci. and Technol. 38(5), 1582-1588.

Shaw L. J., Beaton Y., Glover L. A., Killham K., and Meharg A. A. (2000) Interactions between soil, toxicant, and a lux-marked bacterium during solid phase-contact toxicity testing. Environmental Toxicology and Chemistry 19(5), 1247-1252.

Sopper W. (1993) Municipal Sudge Use in Land Restoration. Lewis.

Sparks D. L., Page A. L., Helmke P. A., Loeppert R. H., Soltanpour P. N., Tabatabai M. A., Johnston C. T., and Sumner M. E. (1996) Methods of Soil Analysis: Part 3 Chemical Methods. Soil Science Society of America.

Tichy R., Rulkens W. H., Grotenhuis J. T. C., Nydl V., Cuypers C., and Fajtl J. (1998)

Bioleaching of metals from soils or sediments. Water Science and Technology 37(8), 119-127.

Tokunaga T. K., Wan J. M., Firestone M. K., Hazen T. C., Olson K. R., Herman D. J., Sutton S. R., and Lanzirotti A. (2003a) In situ reduction of chromium(VI) in heavily contaminated soils through organic carbon amendment. Journal of Environmental Quality 32(5), 16411649.

Tokunaga T. K., Wan J. M., Firestone M. K., Hazen T. C., Schwartz E., Sutton S. R., and Newville M. (2001a) Chromium diffusion and reduction in soil aggregates. Environmental Science \& Technology 35(15), 3169-3174.

Tokunaga T. K., Wan J. M., Firestone M. K., Hazen T. C., Schwartz E., Sutton S. R., and Newville M. (2001b) Chromium diffusion and reduction in soil aggregates. Environ. Sci. and Technol. 35(15), 3169-3174.

Tokunaga T. K., Wan J. M., Hazen T. C., Schwartz E., Firestone M. K., Sutton S. R., Newville M., Olson K. R., Lanzirotti A., and Rao W. (2003b) Distribution of chromium contamination and microbial activity in soil aggregates. Journal of Environmental Quality 32(2), 541-549.

Tyson G. W., Chapman J., Hugenholtz P., Allen E. E., Ram R. J., Richardson P. M., Solovyev V. V., Rubin E. M., Rokhsar D. S., and Banfield J. F. (2004) Community structure and metabolism through reconstruction of microbial genomes from the environment. Nature 428(6978), 37-43. 
von Canstein H., Li Y., Leonhauser J., Haase E., Felske A., Deckwer W. D., and Wagner-Dobler I. (2002) Spatially oscillating activity and microbial succession of mercury-reducing biofilms in a technical-scale bioremediation system. Applied And Environmental Microbiology 68(4), 1938-1946.

von Canstein H., Li Y., Timmis K. N., Deckwer W.-D., and Wagner-Dobler I. (1999) Removal of Mercury from Chloralkali Electrolysis Wastewater by a Mercury-Resistant Pseudomonas putida Strain. Appl. Environ. Microbiol. 65(12), 5279-3445.

von Canstein H., Li Y., and Wagner-Dobler I. (2001) Long-term performance of bioreactors cleaning mercury-contaminated wastewater and their response to temperature and mercury stress and mechanical perturbation. Biotechnology and Bioengineering 74(3), 212-219.

Vulkan R., Zhao F. J., Barbosa-Jefferson V., Preston S., Paton G. I., Tipping E., and McGrath S. P. (2000) Copper speciation and impacts on bacterial biosensors in the pore water of copper-contaminated soils. Environ. Sci. and Technol. 34(24), 5115-5121.

Wagner-Dobler I., Von Canstein H., Li Y., Timmis K. N., and Deckwer W.-D. (2000) Removal of mercury from chemical wastewater by microorganisms in technical scale. Environ. Sci. and Technol. 34(21), 4628-4634.

Wagner-Doebler I., Von Canstein H., Li Y., Timmis K. N., and Deckwer W.-D. (2000) Removal of mercury from chemical wastewater by microorganisms in technical scale. Environmental Science \& Technology 34(21), 4628-4634.

WagnerDobler I., Lunsdorf H., Lubbehusen T., vonCanstein H. F., and Li Y. (2000) Structure and species composition of mercury-reducing biofilms. Applied and Environmental Microbiology 66(10), 4559-4563.

Weijma J., de Hoop K., Bosma W., and Dijkman H. (2002) Biological conversion of anglesite $(\mathrm{PbSO} 4)$ and lead waste from spent car batteries to galena $(\mathrm{PbS})$. Biotechnology Progress 18(4), 770-775.

Zhang H., Zhao F.-J., Sun B., Davison W., and McGrath S. P. (2001) A new method to measure effective soil solution concentration predicts copper availability to plants. Environmental Science \& Technology 35(12), 2602-2607. 



\section{DISCLAIMER}

This document was prepared as an account of work sponsored by the United States Government. While this document is believed to contain correct information, neither the United States Government nor any agency thereof, nor The Regents of the University of California, nor any of their employees, makes any warranty, express or implied, or assumes any legal responsibility for the accuracy, completeness, or usefulness of any information, apparatus, product, or process disclosed, or represents that its use would not infringe privately owned rights. Reference herein to any specific commercial product, process, or service by its trade name, trademark, manufacturer, or otherwise, does not necessarily constitute or imply its endorsement, recommendation, or favoring by the United States Government or any agency thereof, or The Regents of the University of California. The views and opinions of authors expressed herein do not necessarily state or reflect those of the United States Government or any agency thereof or The Regents of the University of California.

Ernest Orlando Lawrence Berkeley National Laboratory is an equal opportunity employer. 